\title{
Does privatization of public sector banks affect stock prices? An event study approach on the Indian banking sector stocks
}

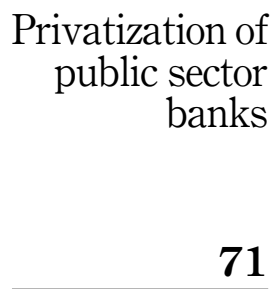

Received 3 June 2021 Revised 22 June 2021 Accepted 20 July 2021

\author{
Department of Commerce, Delhi School of Economics, University of Delhi, \\ New Delhi, India, and \\ Dharen Kumar Pandey \\ P. G. Department of Commerce, Magadh University, Bodh Gaya, India
}

\begin{abstract}
Purpose - With a sample of 22 banks, this study examines the significance of the news contents about the privatization of two public sector banks in India. New information does impact the stock markets. This study provides evidence on how the privatization of public sector banks impacted the returns of the Indian banking sector. Design/methodology/approach - This study employs the standard event study methodology with the market model for estimating the normal returns.

Findings - The statistical results indicate that while the private sector banks experienced positive average abnormal returns on the event day, the cumulative effect of the announcement is negatively significant for both private and public sector banks. The statistical results also provide evidence of information leakage, with significant results before the announcement date. The shorter event windows analysis exhibits significant positive returns in the 5 -days $[-2,+2]$ window for the private sector banks and the entire sample, signifying a positive short-term impact on the private sector banks.

Originality/value - The event study literature captures the impacts of many events. However, to the best of our knowledge, the impacts of the privatization of the Indian public sector banks have never been examined using the event study methodology. Hence, this study anticipates being the first-ever study to fill this gap and extend the available literature in finance. In addition, although we provide Indian evidence, future studies may be oriented to capture cross-country impacts.
\end{abstract}

Keywords Privatization, Indian banking sector, Event study, Market model, Abnormal return

Paper type Research paper

\section{Introduction}

In 1969, the Government of India nationalized the 14 private banks and, in 1980, six private banks accelerated the country's economic growth. Later in 1993, the Bank of India was merged with Punjab National Bank, the State Bank of Saurashtra merged with the State Bank of India (SBI) in 2008, State Bank of Indore merged with SBI in 2009. Other remaining SBI associates and Bhartiya Mahila Bank were merged on 1 April 2017 with SBI and became

\section{JEL Classification - E44, G14, G21, G32}

(C) Varun Kumar Rai and Dharen Kumar Pandey. Published in Asian Journal of Accounting Research. Published by Emerald Publishing Limited. This article is published under the Creative Commons Attribution (CCBY 4.0) licence. Anyone may reproduce, distribute, translate and create derivative works of this article (for both commercial and non-commercial purposes), subject to full attribution to the original publication and authors. The full terms of this licence may be seen at http://creativecommons. org/licences/by/4.0/legalcode

The authors thank Dr. Imam Harymawan, the Editor-in-Chief, Dr. Nadia Anridho, the Associate Editor, and the two anonymous reviewers for their valuable suggestions to improve the quality of the manuscript.

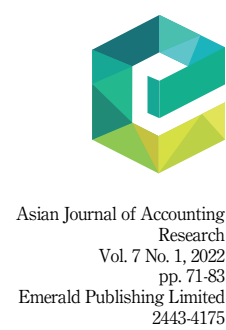

DOI 10.1108/AJAR-06-2021-0078 
AJAR 7,1

India's largest bank. In 2019, Dena Bank and Vijaya Bank were merged with Bank of Baroda. On 30 August 2019, the finance minister of India Smt. Nirmala Sitaraman announced to merge ten public sector banks with four major banks, which was effective from 1 April 2020, and the number of public sector banks reduced to 12 from 27. As per the Narsimha committee of 1991 on Banking Sector Reform, there should be a four-tier banking structure with eight to ten national banks with countywide branches and top banks and local banks at the regional level and rural ranks at the ground level. Merger and acquisition in the banking sector are more significant in the emerging market than the US stock market.

On 21 January 2019, Life Insurance Corporation took over a 51\% stake in IDBI, leading to its conversion into a private bank. Further, the Government of India decided to privatize the two public sector Banks. On 1 February 2021, during the budget announcement, India's finance minister Smt. Nirmala Sitaraman proposed privatizing the two public sector banks and one general insurance company other than IDBI Bank in 2021-2022. Further, only those banks will be considered privatized that were not consolidated recently, because the consolidated banks are still facing complexities and privatizing them to make their operations is more complex. Keeping such issues in mind, the Government of India, with the consultation from the Reserve Bank of India and NITI AYOG, has shortlisted four mid-sized state-run banks for privatization, which include Bank of Maharashtra (13,000 workforces), Bank of India (50,000 workforces), Indian Overseas Bank (26,000 workforces) and Central Bank of India (33,000 workforces). Only two banks will be privatized from these four shortlisted banks in 2021-2022 from mid-sized to small-sized in its first round. Being an efficient market, the transmission of any uncertain news in any economy affects the stock market. Recently, unprecedented news related to the COVID-19 outbreak affected the emerging and developed markets, where the Asian market is affected more than any other (Pandey and Kumari, 2021a). The announcement of privatization of two public sector banks will affect the capital markets immediately. Thus, this study aims to examine the impact of such news on stock prices of the Indian banking sector.

The scope of the study is limited to the banking sector stocks in India. The study contributes to the existing literature in two ways. First, it extends the literature of event studies to examine the impacts of public bank's privatization news on the stock returns of the banking sector stocks. Second, it leaves the scope of future research in the allied sectors as well as cross-country comparative study. Furthermore, cross-sectional regression may be used to find out which bank-specific characteristics impact the cumulative abnormal returns during the transmission of these news in the market.

\section{Literature review}

This section discusses a few literature related to the development of the event study methodology and its application to capture the impacts of various new information on the stock market returns. Dimson (1979) examined whether infrequent share trading leads to biased beta estimates. They used a sample of 421 shares, which were continuously listed in the UK stock exchange for 1955-1974 employing the aggregated coefficient method for estimating beta and concluded that the aggregated coefficient method gave unbiased beta estimates in case of infrequent trading. Brown and Warner (1980) examined the problem of event study methodology on 250 samples of randomly selected 50 securities' monthly return from 1944 to 1971 using mean adjusted, market adjusted and OLS market model and concluded that more complex methodologies do not give any value as compared to a simple OLS market model. Brown and Warner (1985) examined the daily stock return and its impact on event study methodologies on 50 randomly selected securities' daily returns available on the CRSP database from 1962 to 1979. They concluded that event study methods with the OLS market model and parametric tests were adequately defined. The non-normality of data has no impact on the 
methodology of an event study. Corrado (1989) proposed a new non-parametric rank test whose data were taken from the CRSP daily return of 600 firms from 1962 to 1986 and found that the non-parametric rank test gave better results than its parametric test. Bernard and Thomas (1989) employed the event study approach with a different model for estimating abnormal returns and provided evidence for delayed price reaction in the post-earning announcement events. Park (2004) analysed the challenges in conducting a multi-country event study using data of 23 international airlines from 16 countries with 241 international news from 1986 to 1998. The author used the market model and concluded that using a single country model while conducting event study of multiple country may lead to overestimation of alterations in firm's value. Kolari and Pynnönen (2010) examined the problem of cross-sectional correlations in event study with a sample of 1,000 portfolios of 50 securities by using CSRP daily return from 1990 to 2005. They concluded that the test study proposed by them adjusted in cross-correlation and variance inflation for single and multiple-day event windows. The available literature suggests that the event study methodology has been a good tool to study the impact of an event on stock price behaviour. Sajid Nazir et al. (2014) investigated the relationship between uncertain political events and the Karachi Stock Exchange (KSE) from May 1999 to December 2010 using the mean adjusted model in the event study. They concluded that political events impacted the KSE stocks returns and observed that the stock market was more consistent in autocratic structure compared to the democratic structure of governments. Savita and Ramesh (2015) examined the short-term abnormal returns of BSE-listed stocks from May 2013 to June 2014 using event windows such as $(-15,+15),(-2,+2)$ and $(-15,-2)$. They concluded that investors could earn abnormal returns by making a systematic investment during the events of political uncertainty. National elections were significant events that lead to a notable shift in the country's political and economic system. Reddy (2018) examined the stock return volatility of the selected companies and drift of the BSE SENSEX 15 days before and after the general election result, 2014 out of 30 stocks sample was taken from five companies of different sectors and analysed the mean return and volatility of return and concluded that investors should rigorously plan and invest in stocks before, during and after the general elections. Antoniadis et al. (2014) and Pandey and Kumari (2020a) added to the literature of event studies examining the impacts of the merger and acquisitions in the banking sector on the stock returns.

Boutchkova and Megginson (2000) examined the impact of privatization on global capital markets and found that privatization increased the market liquidity, and the number of individual and institutional shareholders was dramatically increased in many countries. Perotti and van Oijen (2001) conducted a study to analyse the role of privatization and political risk on the stock market in emerging economies. They found that resolution of political risk from privatization made rapid growth in emerging economies. Otchere and Chan (2003) conducted a study to examine the intra-industry effects of bank privatization in Australia and concluded that full privatization of banks was more efficient, profitable and robust stock market performance. Clarke and Cull (2005) analysed the political constraints and differential outcomes on the privatization of banks in Argentina. They found that provinces having fiscal problems favoured accepting more layoffs and guaranteeing more of the portfolio of privatized banks in return for a higher price. Sathye (2005) examined the impact of privatization on the performance and efficiency of Indian banks retrieving the data from the performance highlights of banks in the publication of the Indian Banks' Association for 1998-2005 using accounting ratio, i.e. return on assets and deposits per employee and found that financial performance of the partially privatized bank was better than fully public sector banks. Clarke et al. (2005) analysed the privatization bank in developing countries and concluded that a strategically privatized bank in the hand of strategic investors was more efficient rather than a fully government-owned bank. Megginson (2005) studied the objective of the economics of privatization of state-owned banks and concluded that the sale of assets to strategic investors with foreign participation would improve performance and efficiency. 
AJAR 7,1

The author also advocates that the government avoided a 100\% insurance scheme for private banks and set a sound regulatory system without any political influence. Megginson and Sutter (2006) made a study to examine the impact of privatization in developing countries. They concluded that the post-privatization banks' output, profitability, efficiency and capital investments increased while leverage decreased for the divested bank. Miyajima and Yafeh (2007) employed the event study approach to examine the banking crisis in Japan and found that the companies with low credit rating and lower book-to-market value were severely affected. Clarke et al. (2009) analysed the privatization of banks in sub-Saharan Africa about Uganda Commercial Bank. They concluded that privatization of UCBs to Stanbic, i.e. relinquished the government control in the hand of strategic investors having foreign participation improve the financial performance of banks. Ghosh (2010) made a study on the objective of the reaction of the state-owned bank on privatization in India using data of all state-owned banks for 1990-2006 and concluded that partially privatized banks had high profitability and efficiency by lowering the risk. Cull and Spreng (2011) examined the efficiency of bank privatization in Tanzania and found that banks' profitability increased while lending and non-performing assets were low due to less reach to the poor or rural area. Oohama and Asai (2011) conducted a study to examine the economic value of privatization of a Postal Savings Bank in Japan using event study methodology and found that privatization of postal saving banks in Japan had a positive impact. Buigut and Kapar (2020) used event study method to conclude that the Saudi Arabia's banking sector has been positively impacted by Qatar's diplomatic and economic isolation. They found different impacts on the other countries in the Gulf Cooperation Council. Kumar et al. (2020) made a study to examine the impact of the privatization of IDBI Bank in the Indian economy. They concluded that partial privatization improves the efficiency and profitability of the bank. Toshtemirovich and Sayfiddinovich (2020) examined the privatization of commercial banks on the experience of China's banking system for 2006-2016 for 22 banks (11 public sectors and 11 private sector banks) using OLS and panel data approach. They found that the performance of the public sector bank was much lower than that of the private bank in China because the public bank made more reserves which lower the liquidity risk and slow down the profitability.

A few recent studies extend event studies using the COVID-19 events. Heyden and Heyden (2020) made a study to examine the impact of COVID-19 on stocks by using the market model with a sample of 200 trading days from S\&P 500 and the S\&P Europe 350 and concluded that COVID-19 negatively affected the stock market. Phuong (2021) analysed the impact of COVID-19 on banking stock in Vietnam using the event study method proposed by (Fama et al., 1969) and $t$-test on the different observations of all three lockdowns and found that nationwide lockdowns affected stock return negative and significantly while positive and significant on lockdowns in the epidemic area only. Ahmad et al. (2021) examined several black swan event including the COVID-19 outbreak using the event study approach and found that different sectors react differently to these events. Pandey and Kumari (2021b) found that all corporate announcements fail to override the impacts of the global pandemic on the stock returns. Hence, these literature provide evidence for significance of the information contents during different events, although the impacts have been different for different events. The event study methodology is the appropriate method to capture the immediate short-term effect of the information contents on the stock market returns.

Apart from these, a few recent studies have also focused on how public-private status affect risk-taking activities of banks (Samet et al., 2018), impact of liquidity creation on financial stability of banks (Gupta and Kashiramka, 2020) and banking sector productivity convergence (Thota and Subrahmanyam, 2020).

The literature review reveals that the studies investigated the company's financial performance, but none of the studies focus on the impacts of the privatization of public sector banks on the stock returns. Hence, the study extends the available literature to this effect. 


\section{Hypotheses}

The study examines the impacts of news contents of the privatization of two public sector banks on Indian banking sector stocks. The reviewed literature provides evidence to support the institutional theory that new information significantly impacts stock returns. Based on the objectives of the study, the following null hypotheses have been formulated to test the significance:

H1. The news contents of the privatization of two public sector banks do not significantly impact the abnormal returns of the Indian banking sector stocks.

H2. The news contents of the privatization of two public sector banks do not significantly impact the abnormal returns of the public sector stocks.

H3. The news contents of the privatization of two public sector banks do not significantly impact the abnormal returns of the private sector stocks.

\section{Data and research methodology}

\subsection{Data}

We aim to examine the impacts of the event on public and private sector banks. To select a sample that would best represent the population, we initiated searching for the specific sectoral/thematic indices on both the stock exchanges. We found that although BSE has an index for private sector banks, it provides no index for PSU banks. However, separate indices for both the sectors were available on NSE. Since we calculate normal returns using the alpha and beta coefficients of the regression between the stock returns and the respective benchmark index returns, we needed a benchmark index for out sample sets. Accordingly, the NIFTY PSU bank index has been used as benchmark index for the public sector banks and the NIFTY Private Bank Index has been used for the private sector banks. The final sample consists of 22 banks listed on the National Stock Exchange. Only those banks have been considered who form the part of the PSU Bank Index and Private Bank Index of the National Stock Exchange (NSE). The daily closing prices of the sample stocks and the benchmark indices have been collected from the NSE's official website (www.nseindia.com). The details of the sample banks are provided in Table 1 (https://drive.google.com/file/d/ 13BGIXce9l1lmyhlIPEAZOc7glL441F1a/view?usp=sharing).

\subsection{Research methodology}

The Brown and Warner $(1980,1985)$ standard event study methodology has been used. We first of all define the event date, estimation window and event window. The announcement date is 1 February 2021, i.e. the budget announcement date in which the proposal of privatization of two public sector banks was introduced. An estimation window of 90 days has been used $(t-100$ to $t-11)$. The event window consists of 20 days $(t-10$ to $t+10)$. The event timeline is reflected in Figure 1 (https://drive.google.com/file/d/1fXMDIEtEyat9hfL2PCecykcHXlwVMjUq/view? usp $=$ sharing).

We require selecting and applying the estimation model to calculate the estimated daily return to estimate the normal stock return. The ordinary least squares (OLSs) market model is the most widely used estimation model for event studies (Armitage, 1995; Brown and Warner, 1980, 1985; Dyckman et al., 1984; Low et al., 2020; Narain and Gupta, 2018; Pandey and Jaiswal, 2017; Pandey and Kumari, 2020a, b, 2021b; Shah and Arora, 2014). Therefore, we use the market model to calculate the normal return $\left(\mathrm{NR}_{s t}\right)$ as per eq. (1):

$$
\mathrm{NR}_{s t}=\alpha+\beta R_{m t}
$$

Privatization of public sector banks 


\begin{tabular}{llll}
\cline { 2 - 4 } AJAR & Sr. No & Public sector bank in the sample & Private sector bank in the sample \\
\cline { 2 - 4 } & 1 & Union Bank of India & Federal Bank \\
& 2 & Canara Bank & Axis Bank \\
& 3 & J and K Bank & IndusInd Bank \\
& 4 & State Bank of India & CUB \\
$\mathbf{7 6}$ & 5 & Bank of Maharashtra & IDFC First Bank \\
\hline & 6 & Punjab National Bank & ICICI Bank \\
& 8 & Indian Bank & HDFC Bank \\
& 9 & UCO Bank & Bandhan Bank \\
& 10 & Bank of Baroda & Kotak Bank \\
Table 1. & 11 & Indian Overseas Bank & RBL Bank \\
Details of the sample & 12 & Central Bank of India & \\
\hline
\end{tabular}

Figure 1 .

Event timeline

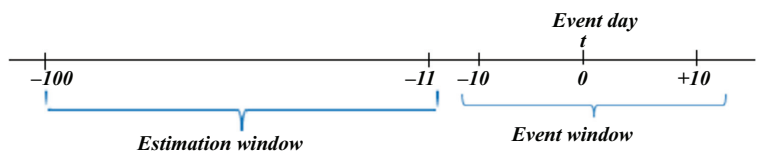

Source(s): Authors'estimation

where $\mathrm{NR}_{s t}$ is the normal return of index $s$ on day $t ; \alpha$ is intercept and $\beta$ is the slope of the regression model; and $R_{m t}$ is the benchmark index return on day $t$. After calculating the normal return using the above model, we have to calculate the abnormal return by subtracting the normal return from the actual return of the stock. The abnormal return can be calculated as per eq. (2):

$$
\mathrm{AR}_{s t}=R_{s t}-\mathrm{NR}_{s t}
$$

where $\mathrm{AR}_{s t}$ is the abnormal return of stock $s$ on time $t ; \mathrm{NR}_{s t}$ is as per eq. (1); $R_{s t}$ is the actual return of the stock $s$ on day $t$, calculated as per eq. (3):

$$
R_{s t}=\log N\left(\frac{\mathrm{CP}_{s t}}{\mathrm{CP}_{s t-1}}\right) \times 100
$$

where $\log N$ is the $\log$ of natural number; $\mathrm{CP}_{s t}$ is the closing price of the stock $s$ on day $t$; and $\mathrm{CP}_{s t-1}$ is the closing price of the stock $s$ on day $t-1$. The calculated abnormal returns for each of the sample banks are aggregated across the banks, and divided by the sample size to calculate the average abnormal return (AAR) as per eq. (4):

$$
\mathrm{AAR}_{t}=\frac{1}{N} \sum_{t=1}^{N} \mathrm{AR}_{s t}
$$

where $\mathrm{AAR}_{t}$ is the aggregate abnormal return, and $N$ is the sample size. These AARs are then used to calculate the daily cumulative average abnormal returns. Further, to test the significance $t$ statistics are used. The $t$-test for AARs and CAARs are calculated as per eqs. (5) and (6) respectively:

$$
\mathrm{AAR}_{t} t=\frac{\mathrm{AAR}_{t}}{\sigma_{N, e t}}
$$




$$
\mathrm{CAAR}_{t} t=\frac{\mathrm{CAAR}_{t}}{\sigma_{N, e t} \sqrt{N_{t+1}}}
$$

Privatization of public sector banks

where $\mathrm{CAAR}_{t}$ is the cumulative average abnormal return on day $t$ and $N_{t+1}$ is the absolute value of the event day plus one. $\sigma_{N, e t}$ is the aggregated $\mathrm{SD}$ of the estimation period abnormal returns calculated as per eq. (7):

$$
\sigma_{N, e t}=\sqrt{\frac{\sum_{s=1}^{N} \sigma_{s, e t}^{2}}{N^{2}}}
$$

where $\sigma_{s, e t} \lim _{x \rightarrow \infty}$ is the SD of daily stock return for the estimation period for each of the sample banks, and $N$ is the sample size.

We compare the calculated $t$-values with the tabulated $t$-values at different significance levels to draw the inference either accepting or rejecting the hypotheses. The critical (tabulated) $t$-values are reflected in Table 2 (https://drive.google.com/file/d/ 1ceE0IZqTT8aWn9721G5MNh_WpuQcA_1Y/view?usp=sharing).

\section{Quantitative results and discussions}

We analyse the daily returns for the sample of 22 banks, further dividing it into two parts: twelve public sector banks and ten private banks.

Table 3 exhibits the average and cumulative average abnormal returns for the public sector banks $(N=12)$, private sector banks $(N=10)$ and the entire sample $(N=22)$ during the event window. While the AAR is significant only on days $t-6$ (negative) and $t+3$ (positive), the cumulative average abnormal returns are significantly negative on days through $t-3$ to $t+2$ and $t+10$. The event day abnormal return has been insignificant. The insignificant return signifies that the event has not impacted the returns of the public sector banks. However, the significantly negative cumulative average abnormal returns a few days before the event signify that there may be some information leakage or anticipation about the announcement that has led to such a cumulative reaction continuing before the event.

The average abnormal returns of the private sector banks are significant on days $t-9$, $t-8, t-5, t-4$ and the event date. While the significant AARs on days $t-9, t-5$ and $t-4$ are negative, those on $t-8$ and event date are positive. The cumulative average abnormal returns are significantly negative through the days $t-5$ to $t+1$. The results indicate that the event has significantly and positively impacted the private sector banks' abnormal returns, although the effect does not continue for more than a day after the event. However, the cumulative effect of the event has been negative.

The average abnormal returns for the entire sample are significant on $t-9, t-8, t-6$, $t-5, t-4, t-3, t, t+3$ and $t+4$. While the AARs on $t-8, t$ and $t+3$ are positively significant, those for the rest are negatively significant. The cumulative average abnormal returns for the entire sample are significantly negative through the days $t-5$ to $t+10$. The results signify that the significance of the news contents could not be denied. Although the event day significant abnormal return is positive, the overall impact has been negative.

\begin{tabular}{lcccc}
\hline Sector & $N$ & Degree of freedom & 1\% significance level & 5\% significance level \\
\hline All data & 22 & 21 & -2.831 to +2.831 & -2.080 to +2.080 \\
PSUs banks & 12 & 11 & -3.106 to +3.106 & -2.201 to +2.201 \\
Private banks & 10 & 9 & -3.250 to +3.250 & -2.262 to +2.262
\end{tabular}

Table 2.

Critical $t$-values at 1 and $5 \%$ significance level 
AJAR

7,1

78

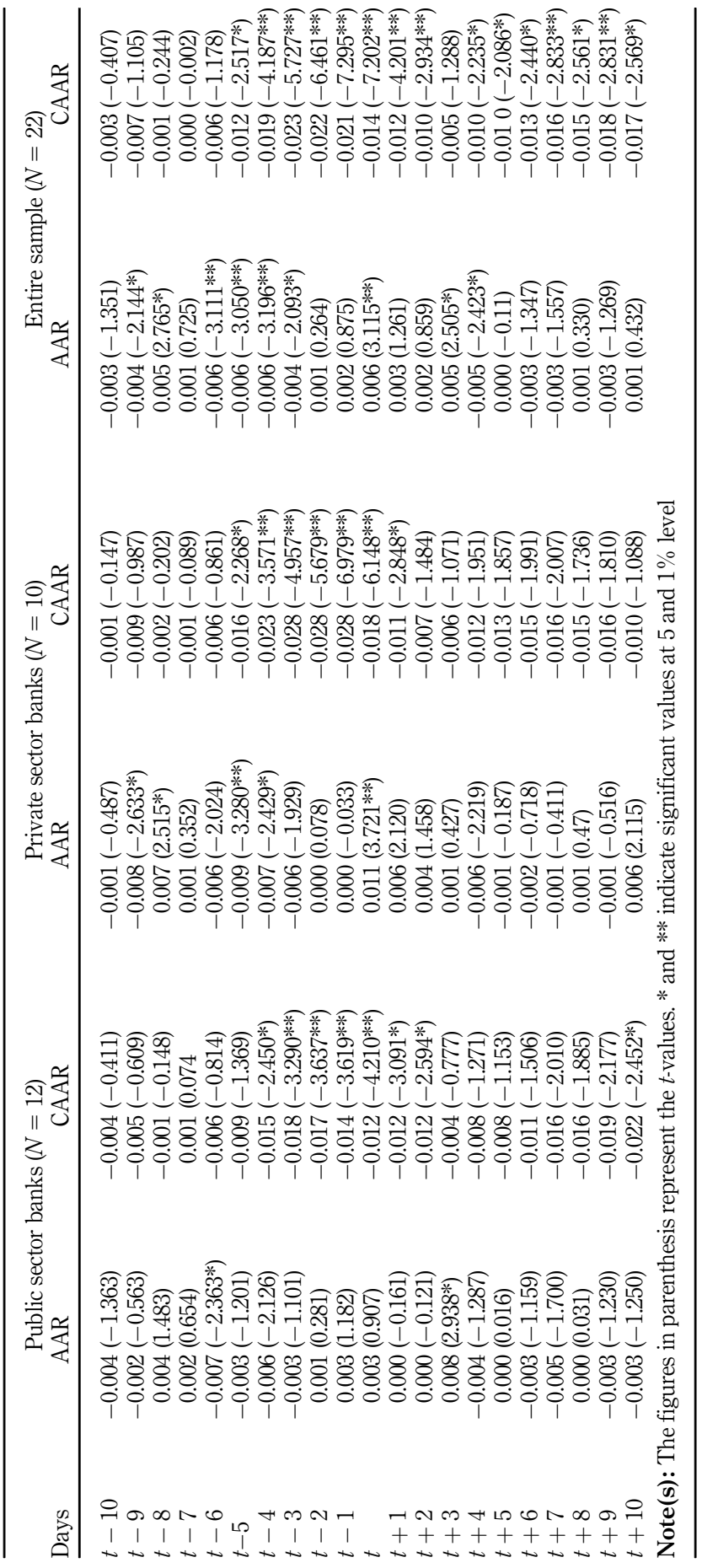

Table 3.

Average and

cumulative average abnormal returns and corresponding $t$-values for public sector banks $(N=12)$ and private sector banks $(N=10)$ 
The announcement has significantly and negatively impacted the banking sector stocks. However, the positive significant abnormal returns on the event date for the private banks indicate a positive impact of the news contents, although not consistent later.

The graphical representation of the AARs and CAARs of the public sector banks, private sector banks, and the entire sample is provided in Figure 2 (https://drive.google.com/file/d/ 1nMfuSz-9UnNhinyJrLd82hHfQ5VYV7Ps/view?usp=sharing). The gap between the AARline and CAAR-line of the public sector banks is seen widening from day $t-6$ onwards with a recovery on day $t+4$, and once again widening after that. However, the movement of the graph does not seem to be very much significant for the public sector banks. The AAR-line and CAAR-line of the private sector banks move apart from the day $t-6$, again moving upward from the event day onwards. The wide gap for the period from $t-6$ to $t+4$ signifies the impacts of the announcement on abnormal returns of the private sector banks. The AAR-line and CAAR-line for the entire sample follow the trend similar to the private sector banks.

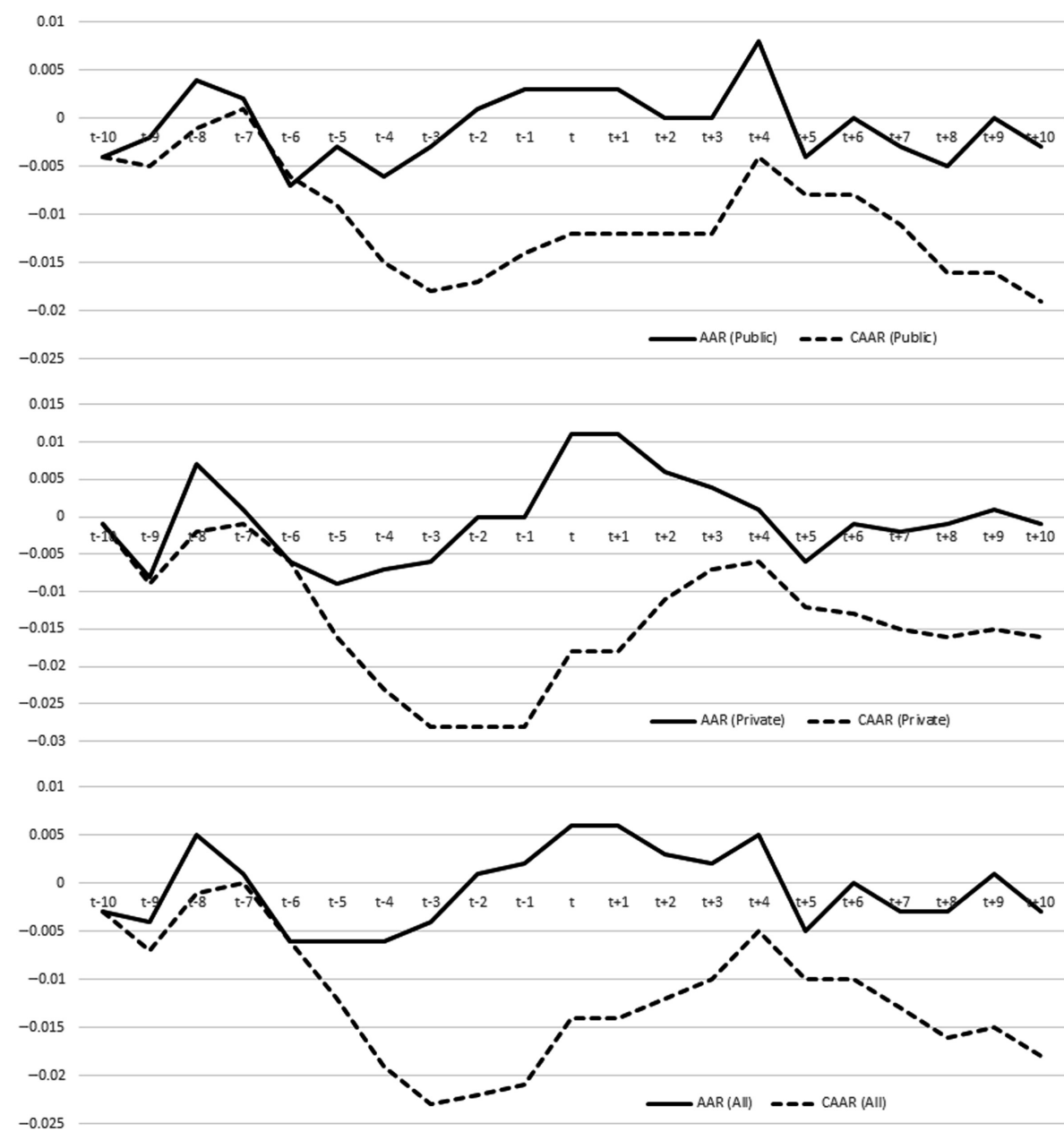

Privatization of public sector banks 
AJAR

7,1

\section{0}

The results of the analysis of the daily average and cumulative average abnormal returns during the event window need to be compared with the shorter event window analysis results. Table 4 reports the average and cumulative average abnormal returns and corresponding $t$-values for public sector banks $(N=12)$, and private sector banks $(N=10)$ in the shorter event windows. None of the shorter window average abnormal returns are significant. The cumulative average abnormal returns for only the 5 -day $[-2,+2]$ window is significantly positive for the private sector banks and the entire sample indicating that the announcement has significantly impacted the private sector banks in the shorter window. The summary of the hypothesis testing is reported in Table 5 (https://rive.google.com/file/d/ 18M4CduYWfkpQVsHpwjaAf3b43smIRnMo/view?usp=sharing).

\section{Conclusions and implications of the study}

With the sample of 22 stocks of the Indian banking sector (twelve public sector banks and ten private sector banks), we employed the (Brown and Warner, 1980, 1985) event study method with the widely used market model to examine the stock price reaction to the news contents related to the privatization of two public sector banks. The statistical results indicate that while the private sector banks experienced positive average abnormal returns on the event day, the cumulative effect of the announcement is negatively significant for both private and public sector banks. The statistical results also provide evidence of information leakage, with significant results before the announcement date. The shorter event windows analysis exhibits significant positive returns in the 5 -day $[-2,+2]$ window for the private sector banks and the entire sample, signifying a positive short-term impact on the private sector banks. The news contents did not impact the average abnormal returns of the public sector banks, signifying that the public sector bank stocks are less sensitive to such information. While speculators may benefit from the significant movements in the stock prices of private sector banks, the public sector bank stocks can be a good inclusion in a moderate risk investment portfolio. The findings support the existence of semi-strong efficiency in the Indian stock market.

The event study literature captures the impacts of many events. However, to the best of our knowledge, the impacts of the privatization of the Indian public sector banks have

Table 4.

Average and cumulative average abnormal returns and corresponding $t$-values for public sector banks $(N=12)$ and private sector banks $(N=10)$ in the shorter event windows

\begin{tabular}{lcccccc}
\hline & \multicolumn{2}{c}{ Public sector banks $(N=12)$} & \multicolumn{2}{c}{ Private sector banks $(N=10)$} & \multicolumn{2}{c}{ Entire sample $(N=22)$} \\
Window & AAR & CAAR & AAR & CAAR & AAR & CAAR \\
\hline$[-7,+7]$ & $-0.001(-0.349)$ & $-0.014(-1.310)$ & $-0.001(-0.338)$ & $-0.014(-1.268)$ & $-0.001(-0.485)$ & $-0.014(-1.820)$ \\
{$[-5,+5]$} & $0.000(-0.061)$ & $-0.002(-0.194)$ & $-0.001(-0.207)$ & $-0.006(-0.656)$ & $0.000(-0.181)$ & $-0.004(-0.575)$ \\
{$[-2,+2]$} & $0.001(0.418)$ & $0.006(0.853)$ & $0.004(1.469)$ & $0.021\left(2.998^{*}\right)$ & $0.003(1.275)$ & $0.013\left(2.602^{*}\right)$
\end{tabular}

Note(s): $[-7,+7],[-5,+5],[-2,+2]$ are the 15 -days, 11-days, and 5-days shorter event windows respectively. *Indicates significant values at $5 \%$ level

\begin{tabular}{lll} 
Sl. & Hypothesis & Results \\
\hline No. & The news contents of the privatization of two public sector banks do not significantly & Rejected \\
H1 & $\begin{array}{l}\text { impact the abnormal returns of the Indian banking sector stocks } \\
\text { The news contents of the privatization of two public sector banks do not significantly }\end{array}$ & Accepted \\
impact the abnormal returns of the public sector stocks & $\begin{array}{l}\text { The news contents of the privatization of two public sector banks do not significantly } \\
\text { impact the abnormal returns of the private sector stocks }\end{array}$ & Rejected \\
&
\end{tabular}

Table 5.

Summary of the hypothesis 
never been examined using the event study methodology. Hence, this study anticipates being the first-ever study to fill this gap and extend the available literature in finance. We examine the impacts on the banking sector. However, further research may focus on the impacts of the announcements of privatization on the allied sectors. In addition, although we provide Indian evidence, future studies may be oriented to capture cross-country impacts. Future research may also try to find the relationship between the bank-specific variables and the cumulative abnormal returns using the cross-sectional regression approach with event study method. The results of the study provide the stock market

Privatization of public sector banks

reaction to privatization news in the Indian banking sector. The results are expected to empower the investors to diversify their short-term portfolios during the transmission of new information related to a particular sector.

\section{References}

Ahmad, W., Kutan, A.M. and Gupta, S. (2021), "Black swan events and COVID-19 outbreak: sector level evidence from the US, UK, and European stock markets", International Review of Economics and Finance, JAI, Vol. 75, pp. 546-557, doi: 10.1016/j.iref.2021.04.007.

Antoniadis, I., Alexandridis, A. and Sariannidis, N. (2014), "Mergers and acquisitions in the Greek banking sector: an event study of a proposal”, Procedia Economics and Finance, Elsevier BV, Vol. 14, pp. 13-22.

Armitage, S. (1995), "Event study methods and evidence on their performance", Journal of Economic Surveys, Vol. 9 No. 1, pp. 25-52.

Bernard, V.L. and Thomas, J.K. (1989), "Post-earnings-announcement drift: delayed price response or risk premium?", Journal of Accounting Research, [Accounting Research Center, Booth School of Business, University of Chicago, Wiley], Vol. 27, pp. 1-36.

Boutchkova, M.K. and Megginson, W.L. (2000), "Privatization and the rise of global capital markets", Financial Management, [Financial Management Association International, Wiley], Vol. 29 No. 4, pp. 31-75.

Brown, S.J. and Warner, J.B. (1980), "Measuring security price performance", Journal of Financial Economics, Vol. 8, pp. 205-258.

Brown, S.J. and Warner, J.B. (1985), "Using daily stock returns: the case of event studies", Journal of Financial Economics, North-Holland Using Daily Stock Returns, Vol. 14, pp. 3-31.

Buigut, S. and Kapar, B. (2020), "Effect of Qatar diplomatic and economic isolation on GCC stock markets: an event study approach”, Finance Research Letters, Elsevier, Vol. 37, 101352.

Clarke, G.R.G. and Cull, R. (2005), "Bank privatization in Argentina: a model of political constraints and differential outcomes", Journal of Development Economics, Vol. 78 No. 1, pp. 133-155.

Clarke, G.R.G., Cull, R. and Shirley, M.M. (2005), "Bank privatization in developing countries: a summary of lessons and findings", Journal of Banking and Finance, Vol. 29 No. 8, pp. 1905-1930.

Clarke, G.R.G., Cull, R. and Fuchs, M. (2009), "Bank privatization in sub-Saharan Africa: the case of Uganda commercial bank", World Development, Vol. 37 No. 9, pp. 1506-1521.

Corrado, C.J. (1989), "A nonparametric test for abnormal security-price performance in event studies", Journal of Financial Economics, North-Holland, Vol. 23 No. 2, pp. 385-395.

Cull, R. and Spreng, C.P. (2011), "Pursuing efficiency while maintaining outreach: bank privatization in Tanzania”, Journal of Development Economics, Vol. 94 No. 2, pp. 254-261.

Dimson, E. (1979), "Risk measurement when shares are subject to infrequent trading", Journal of Financial Economics, Vol. 7 No. 2, pp. 197-226.

Dyckman, T., Philbrick, D. and Stephan, J. (1984), “A comparison of event study methodologies using daily stock returns: a simulation approach", Studies on Current Econometric Issues in Accounting Research, Vol. 22, pp. 1-30. 
AJAR 7,1
Fama, E.F., Fisher, L., Jensen, M.C. and Roll, R. (1969), "The adjustment of stock prices to new information", International Economic Review, Vol. 10 No. 1, pp. 1-21.

Ghosh, S. (2010), "How did state-owned banks respond to privatization? Evidence from the Indian experiment", Annals of Public and Cooperative Economics, John Wiley and Sons, Vol. 81 No. 3, pp. 389-421.

Gupta, J. and Kashiramka, S. (2020), "Financial stability of banks in India: does liquidity creation matter?”, Pacific Basin Finance Journal, Elsevier B.V., Vol. 64, 101439.

Heyden, K.J. and Heyden, T. (2020), "Market reactions to the arrival and containment of COVID-19: an event study", Finance Research Letters, Elsevier BV, Vol. 38, 101745.

Kolari, J.W. and Pynnönen, S. (2010), "Event study testing with cross-sectional correlation of abnormal returns", The Review of Financial Studies, Vol. 23 No. 11, pp. 3996-4025.

Kumar, V., Ganguly, S., Ghosh, P. and Pal, M. (2020), "The impact of privatization of IDBI bank in Indian economy", International Journal of Research in Engineering, Science and Management, Vol. 3 No. 12 , pp. 59-63.

Low, S., Ullah, F., Shirowzhan, S., Sepasgozar, S.M.E. and Lee, C.L. (2020), "Smart digital marketing capabilities for sustainable property development: a case of Malaysia”, Sustainability (Switzerland), MDPI AG, Vol. 12 No. 13, doi: 10.3390/su12135402.

Megginson, W.L. (2005), "The economics of bank privatization”, Journal of Banking and Finance, Vol. 29 No. 8, pp. 1931-1980.

Megginson, W.L. and Sutter, N.L. (2006), "Privatisation in developing countries", Corporate Governance: An International Review, John Wiley and Sons, Vol. 14 No. 4, pp. 234-265.

Miyajima, H. and Yafeh, Y. (2007), “Japan's banking crisis: an event-study perspective”, Journal of Banking and Finance, North-Holland, Vol. 31 No. 9, pp. 2866-2885.

Narain and Gupta, C.P. (2018), "Special dividend announcements by Indian firms", Business Analyst, Vol. 38 No. 2, pp. 3-25.

Oohama, K.-I. and Asai, Y. (2011), "Does privatization of a postal savings bank in Japan have economic value?”, iBusiness, Scientific Research, Vol. 3 No. 3, pp. 244-247.

Otchere, I. and Chan, J. (2003), "Intra-industry effects of bank privatization: a clinical analysis of the privatization of the Commonwealth Bank of Australia", Journal of Banking and Finance, Vol. 27 No. 5, pp. 949-975.

Pandey, D.K. and Jaiswal, A.K. (2017), "Impact of demonetization on Indian stock market-an empirical study", Al-Barkaat Journal of Finance and Management, Diva Enterprises, Vol. 9 No. 2, p. 46.

Pandey, D.K. and Kumari, V. (2020a), "Effects of merger and acquisition announcements on stock returns: an empirical study of banks listed on NSE and NYSE", The Review of Finance and Banking, Vol. 12 No. 1, pp. 49-62.

Pandey, D.K. and Kumari, V. (2020b), "Performance of the Indian tourism and hospitality stocks during the 2019-nCoV outbreak-an event study using stocks listed on the NSE", Orissa Journal of Commerce, Vol. XXXXI No. 2, pp. 19-30.

Pandey, D.K. and Kumari, V. (2021a), "Event study on the reaction of the developed and emerging stock markets to the 2019-nCoV outbreak", International Review of Economics and Finance, Vol. 71, doi: 10.1016/j.iref.2020.09.014.

Pandey, D.K. and Kumari, V. (2021b), "Impacts of corporate announcements on stock returns during the global pandemic: evidence from the Indian stock market", SSRN, doi: 10.2139/ssrn.3851438.

Park, N.K. (2004), "A guide to using event study methods in multi-country settings", Strategic Management Journal, John Wiley and Sons, Vol. 25 No. 7, pp. 655-668.

Perotti, E.C. and van Oijen, P. (2001), "Privatization, political risk and stock market development in emerging economies", Journal of International Money and Finance, Vol. 20 No. 1, pp. 43-69. 
Phuong, L.C.M. (2021), "How COVID-19 impacts Vietnam's banking stocks: an event study method", Banks and Bank Systems, LLC CPC Business Perspectives, Vol. 16 No. 1, pp. 92-102.

Reddy, G. (2018), "Impact of general elections 2014 on Indian stock market with special references to the stock of select companies in BSE”, International Journal of Management Studies, Vol. V, p. 123.

Sajid Nazir, M., Younus, H., Kaleem, A. and Anwar, Z. (2014), "Impact of political events on stock market returns: empirical evidence from Pakistan", Journal of Economic and Administrative Sciences, Vol. 30 No. 1, pp. 60-78.

Samet, A., Boubakri, N. and Boubaker, S. (2018), "Does public-private status affect bank risk taking? Worldwide evidence", Journal of International Financial Markets, Institutions and Money, Elsevier, Vol. 53, pp. 287-306.

Sathye, M. (2005), "Privatization, performance, and efficiency: a study of Indian banks", Vikalpa, SAGE Publications India, Vol. 30 No. 1, pp. 7-16.

Savita and Ramesh, A. (2015), "Return volatility around national elections: evidence from India", Procedia - Social and Behavioral Sciences, Vol. 189, pp. 163-168.

Shah, P. and Arora, P. (2014), "M\&A announcements and their effect on return to shareholders: an event study", Accounting and Finance Research, Sciedu Press, Vol. 3 No. 2, doi: 10.5430/afr. v3n2p170.

Thota, N. and Subrahmanyam, A.C.V. (2020), "Bank total factor productivity convergence: evidence from India”, Finance Research Letters, Elsevier, Vol. 37, 101357.

Toshtemirovich, M.Z. and Sayfiddinovich, M.F. (2020), "Importance of privatisation of commercial banks (experience of China's banking system)", EPRA International Journal of Economics, Business and Management Studies (EBMS), Vol. 7 No. 2, pp. 51-63.

\footnotetext{
About the authors

Varun Kumar Rai is a research scholar in the Department of Commerce, University of Delhi, Delhi. He has a teaching experience of more than six years. He has published two books for students preparing for entrance and competitive examinations. His research interests lie in international business and corporate finance. Varun Kumar Rai is the corresponding author and can be contacted at: varun.dse. du@gmail.com

Dharen Kumar Pandey is an assistant professor in the P.G. Department of Commerce, Magadh University, Bodh Gaya, Bihar. He has ten years industry and teaching experience. His research interests are financial markets, financial econometrics and market efficiency. He has published a number of research papers in various reputed journals including the International Review of Economics and Finance, the International Journal of Financial Markets and Derivatives, the Review of Finance and Banking and the Indian Journal of Commerce.
}

For instructions on how to order reprints of this article, please visit our website: www.emeraldgrouppublishing.com/licensing/reprints.htm Or contact us for further details: permissions@emeraldinsight.com 